\title{
Mother Tongue Textbooks and the Possibilities of Creativity Development through Their Use in Mother Tongue Lessons in Early Primary School
}

\section{Summary \\ Introduction}

Creativity as one of the most desired contemporary human qualities is closely related to self-expression, but self-expression to self-assessment, self-esteem, and further to self-actualisation. Therefore the early primary school stage becomes especially crucial which involves the development of creative abilities as one of the most fundamental tasks. The article focuses on the early primary text-books in the mother tongue (Latvian, Lithuanian, Estonian, Polish, Ukrainian, Russian) in order to clarify to what extent and exactly what kind of creativity promoting tasks the authors include in them.

\section{Aim of the study}

The aim is to analyse the mother tongue early primary school text-books of various nationalities in order to establish the number and type of the tasks promoting children's creativity.

\section{Materials and methods}

Analysis of theoretical literature and the tasks provided by the text-books, a survey of children.

\section{Results}

Mother tongue early primary school text-books, including Latvian, Lithuanian, Estonian, Polish, Ukrainian and Russian by various authors, were analysed for in accordance with their rating for tasks which foster creativity. The pupils were surveyed about the assigned tasks, and the attitudes of different authors for opportunities of fostering creativity in mother tongue lessons were assessed.

\section{Conclusions}

In the early primary school stage it is significant to foster children's creativity during mother tongue lessons as such tasks in opposition to boring and monotonous) are fulfilled with greater enthusiasm and pleasure, so they foster self-assessment, development of positive relationships, and faster achievement of teaching/ learning aims.

Some tasks fostering children's creativity are included in mother tongue early primary school text-books of different nationalities. Nevertheless we have to conclude that some authors pay more attention to them than others. Consequently, text-books do not fulfil their function as an idea bank for the teacher, and the teachers have to make great effort to develop creative, exciting and joyful educational experiences.

Key words: early primary school (Forms 1-4), creativity, Mother Language textbook, task.

\section{Introduction}

Creativity is an important feature of a modern personality that is closely connected with selfexpression where self-expression is connected with self-evaluation, self-awareness and self-actualization. Early primary school is significant because its goal is to promote the development of creative abilities.

To the question: "What could educators and parents do to facilitate a child's creativity?" D. Lieǵeniece responds: 'One of the directions is involvement of the pupils in active learning processes. The fundamental idea is to arrange knowledge formation process so that associations can be developed on the basis of previously acquired knowledge, abilities, skills, avoiding stereotypes, considering a child's predominant learning style (Lieǵeniece 2003). What liberates from stereotypes, how to take into consideration the child's predominant learning style etc. these issues concern educators who are eager to develop a child's 
creativity, which serves as the precondition of its self-actualisation, where A. Maslow (1998) claims as crucial several aspects:

- life as a continuous choice process;

- $\quad$ live, holistic and genuine experience;

- $\quad$ listening to the call of impulses, opportunity to gain an insight into oneself;

- $\quad$ taking responsibility;

- $\quad$ opportunities to express one's honest attitude autonomous to the surrounding opinions;

- $\quad$ ability for compassion and communication with other people;

- $\quad$ ability to find oneself.

How are these aspects of self-actualisation implemented in the work with the mother tongue textbooks, which are considered to serve as 'idea banks' (Cunnigsworth 1998), or represent unused reserves of such 'banks', where not only teachers, but also parents and grandparents can borrow ideas? These are questions which this article has set its goal to searching for answers.

\section{Aim of the study}

The purpose of the study is to provide an overview of mother language (Latvian, Lithuanian, Estonian, Polish, Ukrainian, Russian) textbooks in order to determine what creative tasks are included in the textbooks and to what extent these creative tasks develop pupil's creativity.

\section{Materials and methods}

Analysis of theoretical literature and the tasks provided by the text-books, a survey of children.

\section{Results}

One of the most crucial text-book components is the task, which according to its definition either stimulates creativity or not. Creativity is facilitated by tasks, which demand a search for analogies and associations, which stimulate imagination (visualisation, composition, role-plays etc.) and implement diverse social forms (pair or group work, 'brainstorming', discussions). The main motive stimulating creativity is the human drive to realise oneself, to understand oneself. Also significant is the thought that the motive for creativity comes from ignorance, which serves as good soil for creative potential and freedom (Vidnere 2006), as it facilitates the personality to be open to innovations. Thus, learning is overcoming of ignorance, which can be accelerated or improved if the conditions for self-expression are created. It is essential to maintain the pupil's possibility of choice, which provides both a genuine experience and stimulates the desire to investigate oneself and to express an honest attitude irrespective of surrounding opinions in order to promote pupils to take responsibility and to communicate with other people.

Also there are tasks for early primary school: to develop children's emotions and intellect, as well as to develop creative abilities, promoting self-assessment and relationships, understanding of empathy and cultural differences, comprehension of other nations' cultures (www.isec.gov.lv). Both the textbook authors and teachers have to think how to formulate the tasks to generate the abovementioned processes to achieve the desired results. Nevertheless, the text-books allow us to establishing that the tasks envisaged for the different stages of the lesson and for different learning aims can either stimulate creativity or leave a child indifferent or even bored. During the last few years, the text-books published in Latvia display many good samples, which prove the experience and desire of the authors to create educational aids in compliance with the most recent pedagogical ideas. However, we have to admit reservations, as really stimulating tasks are found next to many monotonous, uninteresting ones. The research aim was not to analyse text-books statistically, but to compile the most interesting tasks, which stimulate and develop creativity. From mother tongue text-books of various nations - mainly Latvian, but also text-books used in Riga's Estonian, Lithuanian, Polish, Ukrainian and Russian schools. It must 
be noticed that the children in the minority schools are learning from the text-books published by the respective states except in the Russian schools where good text-books published by the local authors in Latvia are used.

Although three aspects promoting the creativity were chosen- opportunities of choice, display of attitudes, and taking responsibility, we have to conclude that it is almost impossible to separate them, as most often these possibilities are interconnected and enrich each other. It is pleasant to note the growth of experience by Latvian authors, especially in the text-books published most recently. Such is the text-book "Zile" (Andersone et al. 2005) providing the children with a multitude of opportunities for creativity during Latvian language lessons, as well as displaying the creative works accomplished by the pupils in previous years, for instance, poems. The creative tasks are offered by the authors to stimulate and develop various language skills.

Many of the tasks for developing of writing-skill give opportunities for choice, ask for an attitude and require responsibility, for instance:

- Complete the sentence: I read books about...

- How do you read? Write the words describing (aloud, silently, slowly, mumbling, unwillingly, fluently).

- The pencil was jumping home from school. While jumping it draw various letters. What words can you form from these letters?

- Write what you would like to ask your friend, teacher, doctor, the president of Latvia?

- Imagine that you are looking for a friend, write an advertisement.

- What are you very good at? Write about it.

Tasks to be accomplished by pair work are less common, for instance:

- How many new words can you invent... by using the letters of the word? Compare how you and your deskmate have accomplished the task.

- Together with your desk-mate create and stage a dialogue with an unexpected ending.

Skills to express your ideas, as well as to listen to the ideas expressed by other children are developed by doing the following tasks:

- How can you hear see feelsmelltaste the spring?

- Create a riddle about ...

- What insect would you like to play, why?

- What title could be given to the poem, why?

- What would you advise your guests to see in your town/village/area...?

Taking into consideration the children's skills of reading, the $2^{\text {nd }}$ form text-book (for reading and thinking) by the same authors (Andersone et al. 2000) suggest organising a show of various books and telling about the most recently read book in class.

Fantasy, monologues, argumentation skills and expressive speech is developed by the following tasks:

Create a story based on the pictures.

Pronouncing the paragraph in various ways: pleading, angry, threatening, weeping, and scared.

- How is the story changed, if...

- What do you think what will happen next?

- What fairy-tale characters would you like to make friends with, why?

- Create a new story about Tim (choose any of the titles or invent).

- Read by using an appropriate intonation the extracts, where Winnie the Pooh is thinking about something/ is surprised/is worried.

- Imagine and write a story, where your toys are participating.

- Look at your houseapartment/from a cat's point of view. Do you think is it pleasant for it to live here?

- What would you do instead of the hen?

- If a moth could speak what would it tell about humans? 
In the Language Wisdom text-book for Form 2 'Zïle's author (Ptičkina 2000) makes children think about separate letters, separate words and separate sentences:

- Unscramble words from the jumbled letters, what topic are these words about?

- Create "an idea flower" about ...

- Read the introduction and the final part of the story; create the main body of it.

- Imagine yourself as a bird! Where would you like to fly, what would you like to see?

- Have a good look at the pictures and invent a caption for each of them.

- Create and write a sentence, where all the words begin with the same letter!

- Read fluently and clearly, do it faster and faster!

- What common title could be attached to both texts?

Imagination and expressing an attitude can also be facilitated by such tasks:

Write what the scared mouse can tell when it returns home?

- How could you calm down Duksis?

- If you were a journalist, what would you like to find out about Mince's business trip?

This text-book is also one of the few which provides spaces for self-assessment, for instance:

- Have a good look at your written works! Can you write more neatly?

The Language Wisdom text-book of Zïle's series for Form 4 (Andersone et al. 2002) makes children think about language in general, both about their mother tongue and others, for instance:

- Organise a discussion in class "Why is language needed?"

- How would this poem be read in Russia, the UK or another country?

- In groups, choose one idiom and illustrate it so that it could be understood by a person of another nationality who is not good with the Latvian language.

Body language and other sign languages are not forgotten either, which provide opportunities to work in pairs or groups:

- By using only gestures, facial expressions and movements, express the ideas: "Come here!", "Leave me alone!"

- With the help of pictures write a phrase... Exchange the notes and discuss the result.

- Split up into groups of three people, negotiate who will be ..., ...,.., create and stage the continuation of the text by use of gestures, facial expressions and movements.

This text-book also gives space for self-assessment and assessment by other group members, reminding the necessity to take into consideration the criteria of assessment and to be sensitive, for instance:

- In pairs create a promotion advertisement for the new enterprise "Morica un Co." Assess each other according to their content and in accordance with the enterprise's aims.

- Create a test for your desk-mate (exchange, check, discuss)

- Check and assess, voice your assessment gently.

- What have we learned (summary); which task was the most interesting, what new things have you learned, which task is not clear enough yet, compare your answers with the ones of your desk-mate.

- Take the teacher's role and check if the following conditions are observed in your friends sentences:

- A capital letter at the beginning of the sentence,

- An appropriate punctuation mark at the end,

- The first sentence begins at a red line etc.

Children prefer tasks through which they can express themselves creatively, by fantasy, by work in pairs or groups, for instance, in the text-book "Ar gudru zinu" for Form 3 (2004). The children like the 
following tasks:

- Read in pairs (roles) one conversation from the story with appropriate expression.

- Complete the story by... (if you want, perform it).

- Write a story about the adventures of $N$ and $M$ in the world.

- Tell the story from N's point of view.

- In groups perform an extract of the poem, invent the title.

- Imagine yourself as Winnie the Pooh and speak on his behalf.

- How many questions can you ask about the picture?

- Organise a quiz (the most interesting/ catch question/the most apt).

- Invent an interview with...

- Write a letter to...

- How would you advertise...?

- Choose a proverb, write a story.

- In groups choose an extract from the text, read and perform it (the others have to guess, which extract of the text was performed).

While investigating early primary school text-books of neighbouring countries it is possible to find other creativity fostering examples. Thus Estonian children are often offered various games (incl. Fingers), which are based on the text read and discussed. Several fairy-tales are written as plays which the children stage. The children's interest is also involved by a vocabulary at the end of the text-book, which provides explanations for archaic Estonian words (Hiiepuu, Tungal 2000).

The Lithuanian text-books, for instance (Plentaite, Marcelione 2000; 2005), also encourage children to creative speaking, inviting them to demonstrate the activities described in the text, and recognising and retelling about children's theatre performance pictures included into the text-book. Choice and responsibility is stimulated by suggestions to read books connected with the discussed topics and pictures which can be seen in the text-book. Beside Lithuanian national games, the authors introduce to the children games from other nations which involve cooperation. In Lithuanian early primary school text-books we can find many so called endless fairy-tales, which foster children's creativity and provide an interesting activity to everyone. Only the Lithuanian text-books provide tales based on lies. The tasks make the children involved, but also stimulate them to thinking and taking responsibility; for instance: Create your own tale, where you yourself are the main character. Only don't harm anyone! Organise a contest of the lie tales and choose the King of Lies.

The Ukrainian language text-books of the early primary school, for example, (Вашуленко 2001; Савченко 2002) provide many speeded speech tasks, also based on samples of fairy-tales, as well as tasks, which teach love for the mother tongue and responsibility for it, for example, teach listening to the sounds of the Ukrainian language. The Latvian language text-book authors, for example, Z. Anspoka (2001) also encourage listening to the sounds of the mother tongue.

An interesting creativity fostering task can be found in the Polish text-book (Dobrowolska et al. 2001), where the children are invited to measure the length of a road by using a witch's cane and boot.

The Russian language text-books for early primary school, for example, by E. Right, (Миронина 2000; Домашева 2000), provide much space to comparisons of Russian with Latvian, including dainas (folksongs), proverbs, riddles, fairy-tales, beliefs. The authors encourage children to search for similarities and differences, as well as to tell about family, education process, truth and lies, friendship, good and evil. Such tasks cannot be accomplished without one's own attitude and responsibility, that is, creatively.

\section{Conclusions}

For each person it is important to develop not only the identity of an individual, which allows one to perceive oneself as a part of a nation possessing its peculiar culture, but also to grow into an active and creative personality, which appreciates its own mother tongue. In this respect, there is a special place for the early primary school as it is possible to include in the text-books developed for children content and tasks that encourage a creative education process which will develop the pupils emotionally and 
intellectually. and will shape their self-assessment and positive communicative relationships.

The authors of the Latvian text-books offer children diverse creativity facilitating task formulations, which provide opportunities of choice, express one's attitudes and take responsibility. Nevertheless, there could be more tasks like these. and new ideas can also be borrowed from early primary school text-books of other nations, where one can establish the authors' priorities and strong points in the development of various tasks, for example, in the Lithuanian text-books endless fairy-tales and in the Estonian ones, plays and games etc.

If we consider the text-books as idea banks for teachers and friends of pupils then for fostering of a creative, exiting and joyful teaching/learning process it is important how each tasks is formulated, which encourages children to creative thinking and action - from the lesson's introduction to knowledge and skills self-assessment and assessment, which provide not only individual work, but also task accomplishment in pairs or groups.

\section{References}

1. Andersone, G., Érgle, D., Filatova, M. u. c. (2000). Zïle (latviešu valoda 2. klasei - grāmata lasīšanai un domāšanai. 1. dalja) [Acorn (The Latvian Language for From 2 - Book for Reading and Thinking. Part 1)]. Rīga: Zvaigzne ABC, 88 lpp. (in Latvian).

2. Andersone, G., Ërgle, D., Filatova, M., Golubeva, V., Inole, I. (2005). Zile (latviešu valoda 1. klasei) [Acorn (The Latvian Language for From 1)]. Rīga: Zvaigzne ABC, 109 Ipp. (in Latvian).

3. Andersone, G., Filatova, M., Ptičkina, Â. (2002). Zïle (latviešu valoda 4. klasei) [Acorn (The Latvian Language for From 4)]. Valodas gudrïbu grāmata. Rīga: Zvaigzne ABC, 207 Ipp. (in Latvian).

4. Anspoka, Z. (2001). Lasāmgrāmata 4. klasei [Reader for Form 4]. Rīga: Lielvārds, 176 lpp. (in Latvian).

5. Ar gudru ziṇu [Knowingly] (2004). (2. klasei - latviešu valoda, matemātika, dabaszinības, sociālās zinības). Rīga: RaKa, 87 Ipp. (in Latvian).

6. Cunningsworth, A. (1998). Choosing Your Caoursebook. London, Macmillan Heinemann. p. 153.

7. Dobrowolska, M., Konieczna, A., Dziabaszew, W. (2001). Wesola skola [A School Full of Joy]. 3. klasa. Warszawa: Skola, p. 78 (in Polish).

8. Hiiepuu, E., Tungal, L. Eesti Keele [Estonian Language] (2000). Opik. 2. klass. Tallinn, ASBIT, p. 123 (in Estonian).

9. Lieǵeniece, D. (2003). Kopveseluma pieeja radošas personības veidošanā [A Holistic Approch in Developing a Creative Personality]. In: Radoša personïa 3 (119.-125. Ipp). Rīga: RaKa (in Latvian).

10. Marcelione, E. (2000). Šaltinelis [Source]. 1. kl. Kaunas: Šviesa, p. 105 (in Lithuanian).

11. Plentaite, V., Marcelione, E. (2005). Šaltinis [Source]. 4. kl. Kaunas: Šviesa, p. 175 (in Lithuanian).

12. Ptičkina, Â. (2000). Zïle 2. klasei [Acorn for Form 2]. Valodas gudrïbu grāmata. Rīga: Zvaigzne ABC, 87 Ipp. (in Latvian).

13. Vidnere, M. (2006). Garīgums kā personības kreativitātes kvalitāte [Spirituality as A Quality in Personality's Creativity]. In: Radoša personiba 4 (55.-62. Ipp.). Rīga: RaKa (in Latvian).

14. Вашуленко, М. С., Скрипченко, Н. Ф. (2002). Буквар [AВC book]. Кuів: Освита, p. 157 (in Ukrainian).

15. Домашева, В. Я. (2000). Русский язык [Russian Language]. 3 класс. Pига: Retorika, с. 211 (in Russian).

16. Маслоу, А. (1988). Мотивачия и личность [Motivati on and Personality]. Москва: МГУ, с. 142 (in Russian).

17. Райт, Э., Миронина, Л. (2002). АБэБэГэ Дэйка [АВС book]. Москва, с. 89 (in Russian).

18. Савченко, О. Я. (2002). Читанка 1 [АВС book 1]. Киів: Освита, с. 99 (in Ukrainian).

19. Учебник русского языка. 1 класс [Russian Language. 1st grade] (2000). Рига: Zvaigzne ABC, с. 118 (in Russian).

\section{Prof. Dr. paed. Margarita Kaltigina}

Riga Teacher Training and Educational Management Academy

Address: Imantas 7. Iinija 1, Riga, LV-1083, Latvia

Phone: (+371) 67860682

E-mail: margarita.kaltigina@rpiva.Iv 